\title{
Oral Microbiome and Its Association with Oral Diseases
}

\author{
Minsu Kwon \\ Department of Otorhinolaryngology, Eulji Medical Center, Eulji University School of Medicine, Seoul, Korea
}

\section{구강 미생물군유전체와 구강 질환}

\author{
권 민 수 \\ 을지대학교 의과대학 을지병원 이비인후과학교실
}

\author{
Received September 20,2016 \\ Revised October 14, 2016 \\ Accepted October 18, 2016 \\ Address for correspondence \\ Minsu Kwon, MD, PhD \\ Department of Otorhinolaryngology, \\ Eulji Medical Center, \\ Eulji University School of Medicine, \\ 68 Hangeulbiseok-ro, Nowon-gu, \\ Seoul 01830, Korea \\ Tel +82-2-970-8276 \\ Fax +82-2-970-8275 \\ E-mail minsu014@gmail.com
}

\begin{abstract}
Microbiome means a holistic genomic information of microorganism which usually having symbiotic relationships confer benefits to human body. Breaches in the homeostasis between host and microorganism or alterations of the microbiome are well-known risk factors promoting human diseases. Oral cavity has hundreds of microbes and demonstrates chronic inflammatory conditions by interrelations among microorganisms, foreign bodies, alcohol, and smoking. Oral microbiome also demonstrates a growing evidence of its implication in the etiology of oral diseases including cancer and other systemic diseases. In this review paper, I would introduce to the associated human diseases with oral microbiome and the mechanism how changes in the oral microbiome with its microenvironment leads to the host diseases. And I would also suggest a new research field in otorhinolaryngology connected to oral microbiome.
\end{abstract}

Korean J Otorhinolaryngol-Head Neck Surg 2017;60(2):49-54

Key Words Cancer $\cdot$ Head and neck $\cdot$ Microbiome $\cdot$ Oral cavity $\cdot$ Oral mucositis.

\section{서 론}

세균, 바이러스, 효모 및 진균 등 인체에 존재하는 다양한 미생물은 인간과 체내 항상성(homeostasis)을 유지하며 공생 관계에 있다. 이러한 미생물의 수는 인간 세포의 10배 이상이 며 그들이 보유하는 유전자 정보는 인간 유전체(genome) 수의 수백 배에 해당된다. ${ }^{1)}$ Microbiome은 second genome으로도 불리며 인체에 공존하는 미생물의 총체적 유전정보를 의미 한다. 미생물이 인간 질환에 미치는 영향력이 매우 크다는 사 실이 알려지면서 microbiome에 대한 연구가 이슈화되었고, 2008년에는 미국 National Institutes of Health 주도하에 'Human Microbiome Project(HMP)'가 조직되어 이에 대한 세계적 관심과 각국의 경쟁적 연구가 현재 진행 중이다. ${ }^{2)}$ 또 한 2016년 5월 미국 행정부에서 오바마 대통령의 임기 마지 막 과학 프로젝트로 'National Microbiome Initiative'를 발 표하기도 하였다. ${ }^{3)}$

인체 미생물은 피부, 구강, 위장관, 호흡기, 생식기 등 여러
부위에 존재하는데 이 중 가장 다수의 다양한 종류의 미생물 이 존재하는 기관이 위장관이다. 따라서 장내 미생물에 대한 연구가 현재까지 가장 활발히 진행되어 있으며 장내 미생물이 염증성 장관 질환(inflammatory bowel disease)과 위장관 암 외에도 타 장기 종양, 심장질환 및 각종 대사질환과 면역질환 등에도 영향을 미치는 것으로 밝혀졌다. ${ }^{4)}$ 최근에는 소화와 호흡의 기시부인 구강 내 미생물의 변화가 다양한 질병과 연 관됨이 밝혀지면서 점차 구강 내 microbiome에 대한 관심이 높아지고 있다. ${ }^{5-8)}$ 또한 구강은 다른 집락지에 비해 미생물 검 체 취득이 용이하고, 미생물-미생물/미생물-인체 간 상호작 용 기전 연구에 필요한 고도로 구조적이고 탄력적인 biofilm 을 형성하고 있다는 측면에서 구강 내 microbiome에 대한 연 구 필요성이 강조되고 있다. ${ }^{9)}$

본 종설에서는 병적인 구강 미생물의 종류를 밝혀내는 분 자생물학적 방법과 현재까지 알려진 구강 내 미생물이 질병을 일으키는 기전에 대해 기술하였다. 그리고, 특히 구강 내 질환 에 초점을 두고, 이비인후과 질환과 구강 내 미생물과의 상 
관성에 대해 살펴보았으며, 향후 구강 내 미생물에 관련된 연 구 방향을 이비인후과의의 관점에서 제시하고자 한다.

\section{Oral Microbiome의 검출방법}

과거에는 microbiome 검출에 배양 기법(culture method) 을 이용하였는데, 이는 배양이 어려운 다양한 균주를 간과할 가능성이 높아 민감도가 매우 낮은 방법이다. 2000년대에 들 어서는 단일염기다형성분석(pyrosequencing)과 같은 고출력 (high-throughput)의 차세대 염기서열분석법(next-generation sequencing)이 도입됨으로써 DNA 염기서열분석(sequencing) 비용이 급감하여 microbiome 연구에도 활발히 적용되고 있 다. 원핵생물(prokaryotic)의 ribosome 중 $30 \mathrm{~S}$ 하부단위인 $16 \mathrm{~S}$ ribosomal RNA에 대한 pyrosequencing은 현재 microbiome 분석에 보편적으로 사용되는 방법으로 전통적 염기서 열분석법에 비해 비용 대비 효율적이고 상세한 분석을 가능 하게 한다. ${ }^{5}$

또 다른 널리 사용되는 분석법으로는 Human Oral Microbe Identification Microarray(HOMIM)가 있는데, 이는 300 400 개의 잘 알려진 구강 미생물에 대해 이미 구축된 microarray 를 바탕으로 분석하는 방법으로, 신속하고 간편하다는 장점 이 있으나 제한된 종류만 가능하다는 한계가 있다. ${ }^{10)}$ Pyrosequencing과 HOMIM을 비교하였을 때 문(phylum)과 속(genus) 단계까지는 결과가 일치하였으나, pyrosequencing이 보 다 광범위한 분류군 파악과 높은 민감도를 보이고 기존의 알 려지지 않은 균주 확인을 할 수 있는 장점을 보였다. ${ }^{11}$

Metagenomic sequencing은 비용 대비 효율성이 점차 향 상되고 있고 위의 두 방법과는 달리 미생물의 전체 genome 을 분석할 수 있으며 세균 표현형과 기능적 측면의 상관성을 파악할 수 있는 장점이 있어서 점차 주목 받고 있다. ${ }^{12}$ 상기 세 가지 방법들의 특성에 대해서는 Table 1에 정리하였다.

\section{Oral Microbiome이 질병을 일으키는 기전}

구강을 포함한 인체 점막은 감염, 외상, 음식물 및 생식세포 돌연변이(germline mutation) 등으로 인한 손상 위험이 상 재하는데, 점막 방어벽이 손상되면 대부분 즉각적으로 회복 되고 조직 항상성이 유지된다. 그러나 인체-미생물 간 복원 력에 장애가 생기면 영구적인 점막 방어벽의 손상을 유발하 며 이로 인해 각종 질환이 발생하게 된다. Microbiome은 손 상된 인체 점막에서 세포의 증식과 사멸을 변화시키거나 면 역체계를 방해하며 세포 대사에 영향을 미쳐서 암을 포함한 각종 질병을 일으키는 것으로 알려져 있다(Fig. 1). ${ }^{13)}$

구강암을 포함한 소화기계 암 발생의 주요 원인으로 음주 와 흡연을 들 수 있는데, 구강 미생물은 상기 두 가지 암 발생 요인의 효과를 증강시키는 것으로 알려져 있다. ${ }^{5)}$ 알코올(에 탄올) 자체는 강력한 발암 물질은 아니지만 구강 미생물이 에탄올 대사물인, 생체 내외 실험에서 유전체 독성과 발암 물 질로 입증된, 아세트알데하이드(acetaldehyde)의 생성을 촉진 시키는 것으로 밝혀졌다. ${ }^{14-16)}$ 그리고 담배에는 여러 종류의 발 암 물질이 있는데, 구강 미생물은 특히 강력한 발암 물질인 니트로사민(nitrosamines) 생성을 촉진시키는 것으로 알려져 있다. ${ }^{5,17)}$ 또한 흡연이 음주로 인한 아세트알데하이드 생성을 촉진시키는데, 이 과정에서도 구강 미생물이 관여한다고 밝 혀졌다. ${ }^{5}$ 즉, 구강 내 미생물은 담배와 알코올 대사에 관여하 여 발암성 대사산물 발생을 증가시켜 구강 및 소화기계 암 발 생을 유발한다.

일부 구강 미생물은 자체 독소와 인체 면역반응을 통해 만 성적 염증을 유발하며 이 또한 각종 질환 발생의 기전이 된다. 형질인식 수용체인 toll-like receptors(TLRs)는 인체의 선천 성 면역 세포들에 존재하며 미생물의 pathogen-associated molecular patterns(PAMPs)와 결합하여 $\mathrm{NF}-\kappa \mathrm{B}$ 경로를 활 성화시킴으로써 일련의 염증반응과 세포자멸사(apoptosis)를

Table 1. Pros and cons of assays for identification of human oral microbiome

\begin{tabular}{|c|c|c|}
\hline 16S rRNA pyrosequencing & HOMIM & Metagenomics \\
\hline Partial 16S rRNA gene sequencing & Microarray-based 16S rRNA hybridization & Entire microbiome gene sequencing \\
\hline Broad detection range of taxa & $\begin{array}{l}\text { Focused detection of common known } \\
\text { species }\end{array}$ & Broad detection range of taxa \\
\hline Detection of unclassified microbes & $\begin{array}{l}\text { Custom array-based approach, covered } \\
\text { by reference sequences }\end{array}$ & $\begin{array}{l}\text { Possible to infer functional and phenotypic } \\
\text { relationships for gene families }\end{array}$ \\
\hline Quantification based on sequence reads & $\begin{array}{l}\text { Quantification based on relative intensity } \\
\text { score }\end{array}$ & Quantification based on sequence reads \\
\hline Relatively high assay cost & Relatively low assay cost & Highest assay cost \\
\hline Relatively more labor intensive & Relatively less labor intensive & Most labor/data intensive \\
\hline
\end{tabular}

HOMIM: human oral microbe identification microarray, rRNA: ribosomal RNA 

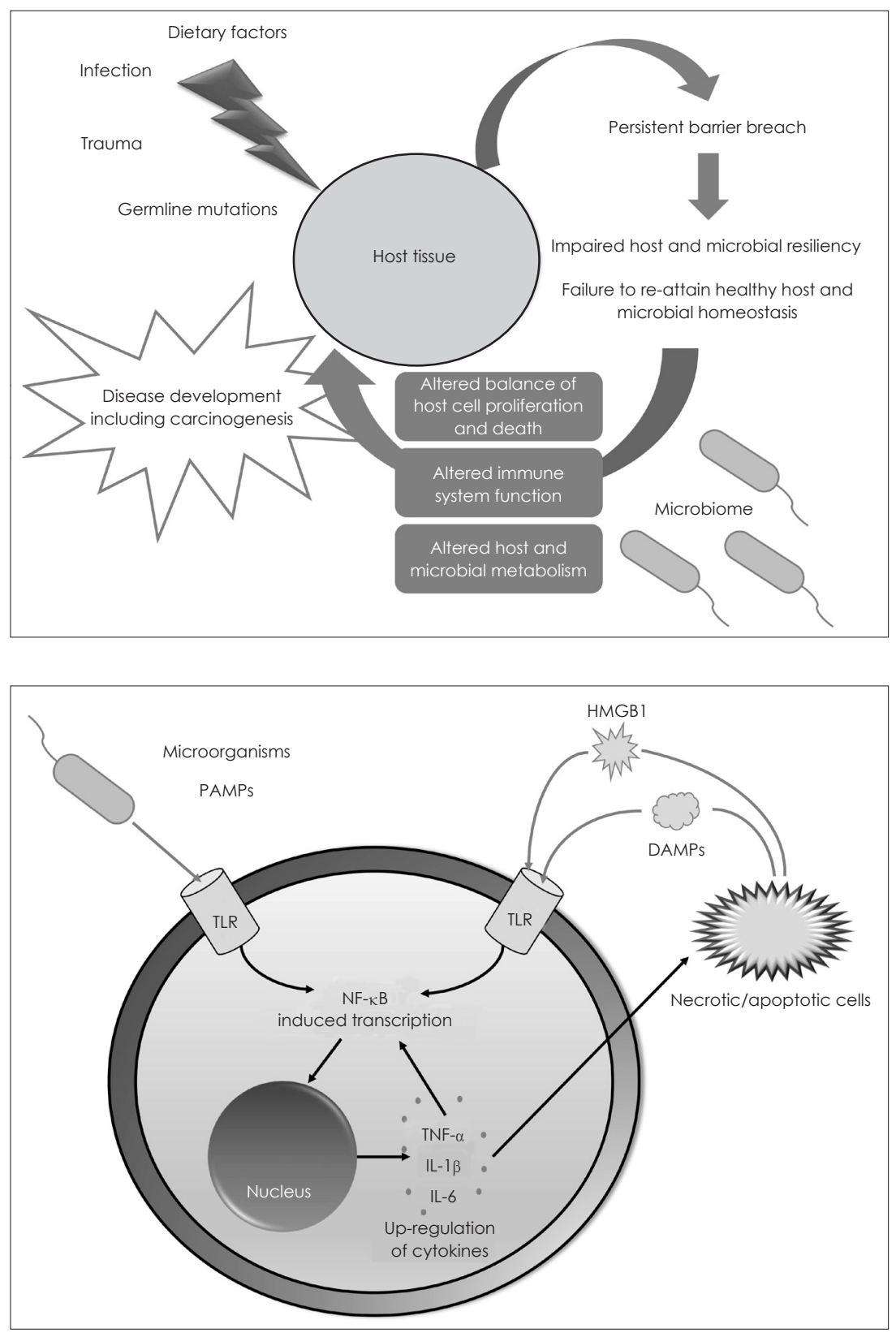

Fig. 1. The path from health to disease at mucosal sites and the microbiome's contribution. Human mucosa are subject to constant environmental insults and injuries including infections, trauma, dietary factors, and germline mutations and these can contribute to breach of the mucosal barriers. Impaired host or microbial resiliency contributes to persistent barrier breach and a failure to restore homeostasis. In these settings, the microbiome may influence disease development including carcinogenesis by 1) altering host cell proliferation and death, 2) perturbing immune system function, and 3 ) influencing metabolism within a host.

Fig. 2. Molecular pathways involved in microbiome-host interactions and the development of human diseases. The detection of microbial components (PAMPs) and endogenous damage-associated molecular patterns (DAMPs) and high-mobility group box-1 (HMGB1) by toll-like receptors (TLRs) triggers a cascade of cellular signals, resulting in activation of NF-KB that contribute to amplify proinflammatory cytokines and apoptosis via upregulation of the innate immune response of the host cells. IL: interleukin, NF-kB: nuclear factor-KB, PAMP: pathogen-associated molecular pattern, TNF: tumor necrosis factor.
유발한다(Fig. 2). 이러한 미생물-인체 간 항상성 파괴로 인해 발생하는 만성적 염증반응은 세포 증식과 사멸의 균형을 변 화시키고 면역체계 이상을 초래하여 구강암과 구내염 등 각 종 질병을 일으킨다. ${ }^{18,19)}$

\section{Oral Microbiome과 질환}

병적인 구강 microbiome을 살피기 전에 먼저 정상적인 구강 내 미생물 구성을 알아보는 게 필요할 것이다. 여러 선행연구 들에서 건강한 사람에서의 구강 microbiome을 분석하였고, Firmicutes, Bacteroidetes, Proteobacteria, Fusobacteria,
Actinobacteria 등이 정상적으로 흔히 존재하는 문으로 확인 되었으며, 가장 흔한 속으로는 순서대로 Streptococcus, Prevotella, Veillonella, Neisseria, Haemophilus 등이었다. ${ }^{20-22)}$ 물론 개인별 다양성과 검체 채취 부위에 따라 microbiome 구성의 차이가 있을 수 있지만, 개인별, 인종별, 국가별 차가 전반적으로 그리 크지 않은 것으로 확인되었다. ${ }^{17)}$ 구강 내 정상 microbiome은 앞서 언급한 $\mathrm{HMP}$ (http://www.hmpdacc.org) 와 Human Oral Microbiome Database(http://www.homd. org) 관련 웹사이트에서 확인할 수 있다. 


\section{구강암}

불량한 구강위생과 치주질환이 구강암 발생의 위험요인임 은 잘 알려진 사실이다. 그리고 그에 따른 구강 microbiome 의 변화가 구강암 발생과 연관됨을 입증할 만한 연구도 증가 하고 있으나 현재까지는 어떤 특정 종류의 미생물이 직접적 인 구강암 발생의 요인이라고는 단정짓기 어려운 상태이다. 과 거 배양 기반 연구와 최근의 sequencing을 이용한 것에서의 상이한 결과가 원인 중 하나로 지적된다. 즉, 배양 기법을 이용 한 연구들에선 Exiguobacterium oxidotolerans, Prevotella melaninogenica, Staphylococcus aureus, Veillonella parvula, Micrococcus species 등이 종양 부위에서 많이 확인되며 상대적으로 혐기성 균주가 차지하는 비율이 높다고 보고하였 다. ${ }^{23-25)}$ 반면 sequencing을 이용한 최근 연구들에서는 Firmicutes, Bacteroidetes, Actinobacteria, Fusobacteria 등의 문이 종양 조직에서 많이 확인되었고, Streptococcus salivarius, Streptococcus gordonii, Gemella haemolysans, Gemella morbillorum, Johnsonella ignava, Streptococcus parasanguinis, Prevotella species 등이 종양 조직에 선택적으로 관찰되는 microbiome이라고 보고하였다. ${ }^{26-28)}$ 일부 특정 microbiome과 암 발생의 인과관계를 입증하기 위한 연구도 많 이 진행되었는데, Streptococcus anginosus와 Helicobacter pylori가 한때 식도암을 포함한 두경부암에서 원인 미생물로 추정이 되었으나 후속 연구들에서는 일치하지 않는 결과가 나 오고 연구 방법론적 문제가 지적되어 그 근거가 약해졌다. ${ }^{29,30)}$ 한편으로는 치주염의 주 원인균인 Porphyromonas gingiva$l i s$ 가 구강암 발생과 높은 연관성을 보인다는 연구가 최근 다 수 보고되고 있어서 향후 후속 연구들을 주목해 볼 필요가 있을 것이다. ${ }^{31-34)}$

\section{구내염}

구내염은 이비인후과의사가 흔히 접하는 질환으로, 특히 항 암방사선 치료를 받는 암 환자에서 발생하는 것은 심한 통증 과 식이 장애 및 삶의 질 저하를 유발하여 환자 생존에도 영향 을 미칠 수 있는 심각한 문제가 되기도 한다. ${ }^{35)}$ 구강 microbiome의 변화가 구내염의 주요 원인임은 잘 알려져 있고, 앞서 언급한 바와 같이, 숙주세포의 TLRS와 미생물의 PAMPs를 통한 선천성 면역반응의 활성화가 구내염을 유발하는 주 기 전이다. ${ }^{18)}$ 구강 microbiome의 변화와 구내염의 상관성에 대 해 항암치료나 이식 후 면역억제 치료를 받는 환자에서 주로 연구가 이뤄졌는데, 세균 중에는 Gemella haemolysans와 Streptococcus mitis, 진균 중에는 Porphyromonas gingivalis, Parvimonas micra, Treponema denticola, Fusobacterium nucleatum, Candida glabrata 등이 구내염 환자에서 많이 발견
되었다. ${ }^{36,37)}$ 방사선 치료를 받는 두경부암 환자의 구내염에 대 한 연구에서는 4개의 문(Actinobacteria, Bacteroidetes, Firmicutes, Proteobacteria)과 11개의 속(Streptococcus, Actinomyces, Veillonella, Capnocytophaga, Derxia, Neisseria, Rothia, Prevotella, Granulicatella, Luteococcus, Gemella)이 방사선 치료 후 구내염 환자에서 현저히 증가한다고 보고하 였다. ${ }^{38)}$ 하지만 안타깝게도 구내염과 구강 microbiome에 관 한 여러 연구에도 불구하고 아직까지도 정확한 병태생리는 알 수 없는 상태인데, 예방적 항생제 사용 등의 구강 microbiome 의 조절을 위한 중재적 치료가 구내염을 예방하는 효과를 전 혀 보이지 않은 것이 결정적인 이유일 것이다. ${ }^{39)}$

\section{기타 질환}

치주염 등의 구강 질환이 위암이나 췌장암과 같이 인접하 지 않은 장기의 암 발생은 물론 심혈관계 질환이나 당뇨와도 연관되어 있고, 구강 질환의 치료 시 상기 질환들의 개선을 보 인다는 연구 결과들은 구강 microbiome이 인체의 전신적 질 환 발생에 중요한 원인이 될 수 있음을 시사한다. ${ }^{5)}$ 하지만 현 재까지의 연구는 구강 microbiome의 변화가 각종 질환에서 관찰되는 현상학적인 결과에 국한되어 있고, 인과관계를 구 체적으로 입증하기에는 한계가 있다. 즉, 각종 질환의 발생으 로 인해 구강 microbiome의 변화가 단순히 관찰될 가능성에 대한 배제와 특정 microbiome에 대한 중재가 질병 발생을 예 방할 수 있음이 입증되어야만 구강 microbiome에 대한 연구 가 환자 치료에 있어서 혁신적이고 실질적인 도움을 줄 수 있 을 것이다.

\section{구강 Microbiome 연구의 미래}

구강 microbiome과 이비인후과 질환의 상관관계에 대한 연구 가능성은 무궁무진할 것이다. 단적인 예가 타액선 질환 일 것인데, 아직까지 타액선에 발생하는 암의 특징적인 위험 인자는 거의 알려져 있지 않으며 타액 내 microbiome이 이에 대한 실마리를 제공해 줄 수 있을 것으로 생각된다. 그리고 또 다른 난치 질환인 구강 건조증(xerostomia)과 구강 작열감 증후군(burning mouth syndrome) 등과도 구강 microbiome 이 연관되어 있을 것으로 예상된다. 최근에는 구강 내 Fusobacterium 상태가 췌장암의 예후인자로서의 가능성이 보고 되었는데, 구강 microbiome이 두경부암에서도 치료 반응성 과 부작용에 대한 예측 지표로 이용될 수 있을 것이다. ${ }^{40)}$ 마 지막으로, 최근 뜨거운 감자가 되고 있는, 면역치료(immunotherapy)에서도 인체 내 microbiome이 치료 반응에 결정 적인 영향을 미칠 가능성이 제기되면서 향후 이에 대한 주지 
와 구강 microbiome을 이용한 두경부암에서의 연구 가능성 에 대해서도 관심을 가질 필요가 있을 것이다. ${ }^{13,41)}$

\section{REFERENCES}

1) Gill SR, Pop M, Deboy RT, Eckburg PB, Turnbaugh PJ, Samuel BS, et al. Metagenomic analysis of the human distal gut microbiome. Science 2006;312(5778):1355-9.

2) NIH HMP Working Group, Peterson J, Garges S, Giovanni M, McInnes P, Wang L, et al. The NIH Human Microbiome Project. Genome Res 2009;19:2317-23.

3) Bouchie A. White House unveils National Microbiome Initiative. Nat Biotechnol 2016;34(6):580.

4) Kau AL, Ahern PP, Griffin NW, Goodman AL, Gordon JI. Human nutrition, the gut microbiome and the immune system. Nature 2011; 474(7351):327-36.

5) Ahn J, Chen CY, Hayes RB. Oral microbiome and oral and gastrointestinal cancer risk. Cancer Causes Control 2012;23(3):399404.

6) Wade WG. The oral microbiome in health and disease. Pharmacol Res 2013;69(1):137-43.

7) Shoemark DK, Allen SJ. The microbiome and disease: reviewing the links between the oral microbiome, aging, and Alzheimer's disease. J Alzheimers Dis 2015;43(3):725-38.

8) Slocum C, Kramer C, Genco CA. Immune dysregulation mediated by the oral microbiome: potential link to chronic inflammation and atherosclerosis. J Intern Med 2016;280(1):114-28.

9) McLean JS. Advancements toward a systems level understanding of the human oral microbiome. Front Cell Infect Microbiol 2014;4:98.

10) Colombo AP, Boches SK, Cotton SL, Goodson JM, Kent R, Haffajee $\mathrm{AD}$, et al. Comparisons of subgingival microbial profiles of refractory periodontitis, severe periodontitis, and periodontal health using the human oral microbe identification microarray. J Periodontol 2009; 80(9):1421-32.

11) Ahn J, Yang L, Paster BJ, Ganly I, Morris L, Pei Z, et al. Oral microbiome profiles: $16 \mathrm{~S}$ rRNA pyrosequencing and microarray assay comparison. PLoS One 2011;6(7):e22788.

12) Sharpton TJ. An introduction to the analysis of shotgun metagenomic data. Front Plant Sci 2014;5:209.

13) Garrett WS. Cancer and the microbiota. Science $2015 ; 348(6230)$; 80-6.

14) Wang M, McIntee EJ, Cheng G, Shi Y, Villalta PW, Hecht SS. Identification of DNA adducts of acetaldehyde. Chem Res Toxicol 2000;13(11):1149-57.

15) Langevin F, Crossan GP, Rosado IV, Arends MJ, Patel KJ. Fancd2 counteracts the toxic effects of naturally produced aldehydes in mice. Nature 2011;475(7354):53-8.

16) Homann N, Jousimies-Somer H, Jokelainen K, Heine R, Salaspuro $\mathrm{M}$. High acetaldehyde levels in saliva after ethanol consumption: methodological aspects and pathogenetic implications. Carcinogenesis 1997;18(9):1739-43.

17) Wang L, Ganly I. The oral microbiome and oral cancer. Clin Lab Med 2014;34(4):711-9.

18) Vasconcelos RM, Sanfilippo N, Paster BJ, Kerr AR, Li Y, Ramalho $\mathrm{L}$, et al. Host-microbiome cross-talk in oral mucositis. J Dent Res 2016;95(7):725-33.

19) Vanhoecke B, De Ryck T, Stringer A, Van de Wiele T, Keefe D. Microbiota and their role in the pathogenesis of oral mucositis. Oral Dis 2015;21(1):17-30.

20) Aas JA, Paster BJ, Stokes LN, Olsen I, Dewhirst FE. Defining the normal bacterial flora of the oral cavity. J Clin Microbiol 2005;43(11): 5721-32.

21) Nasidze I, Li J, Quinque D, Tang K, Stoneking M. Global diversity in the human salivary microbiome. Genome Res 2009;19(4):636-43.
22) Lazarevic V, Whiteson K, Hernandez D, François P, Schrenzel J. Study of inter- and intra-individual variations in the salivary microbiota. BMC Genomics 2010;11:523.

23) Nagy KN, Sonkodi I, Szöke I, Nagy E, Newman HN. The microflora associated with human oral carcinomas. Oral Oncol 1998;34(4): 304-8.

24) Hooper SJ, Crean SJ, Lewis MA, Spratt DA, Wade WG, Wilson MJ. Viable bacteria present within oral squamous cell carcinoma tissue. J Clin Microbiol 2006;44(5):1719-25.

25) Bolz J, Dosá E, Schubert J, Eckert AW. Bacterial colonization of microbial biofilms in oral squamous cell carcinoma. Clin Oral Investig 2014;18(2):409-14.

26) Pushalkar S, Mane SP, Ji X, Li Y, Evans C, Crasta OR, et al. Microbial diversity in saliva of oral squamous cell carcinoma. FEMS Immunol Med Microbiol 2011;61(3):269-77.

27) Pushalkar S, Ji X, Li Y, Estilo C, Yegnanarayana R, Singh B, et al. Comparison of oral microbiota in tumor and non-tumor tissues of patients with oral squamous cell carcinoma. BMC Microbiol 2012; 12:144.

28) Schmidt BL, Kuczynski J, Bhattacharya A, Huey B, Corby PM, Queiroz EL, et al. Changes in abundance of oral microbiota associated with oral cancer. PLoS One 2014;9(6):e98741.

29) Morita E, Narikiyo M, Yano A, Nishimura E, Igaki H, Sasaki H, et al. Different frequencies of Streptococcus anginosus infection in oral cancer and esophageal cancer. Cancer Sci 2003;94(6):492-6.

30) Okuda K, Ishihara K, Miura T, Katakura A, Noma H, Ebihara Y. Helicobacter pylori may have only a transient presence in the oral cavity and on the surface of oral cancer. Microbiol Immunol 2000; 44(5):385-8.

31) Ahn J, Segers S, Hayes RB. Periodontal disease, porphyromonas gingivalis serum antibody levels and orodigestive cancer mortality. Carcinogenesis 2012;33(5):1055-8.

32) Inaba $H$, Sugita $H$, Kuboniwa $M$, Iwai $S$, Hamada $M$, Noda $T$, et al. Porphyromonas gingivalis promotes invasion of oral squamous cell carcinoma through induction of proMMP9 and its activation. Cell Microbiol 2014;16(1):131-45.

33) Galvão-Moreira LV, da Cruz MC. Oral microbiome, periodontitis and risk of head and neck cancer. Oral Oncol 2016;53:17-9.

34) Javed F, Warnakulasuriya $S$. Is there a relationship between periodontal disease and oral cancer? A systematic review of currently available evidence. Crit Rev Oncol Hematol 2016;97:197-205.

35) Villa A, Sonis ST. Mucositis: pathobiology and management. Curr Opin Oncol 2015;27(3):159-64.

36) Napeñas JJ, Brennan MT, Coleman S, Kent ML, Noll J, Frenette G, et al. Molecular methodology to assess the impact of cancer chemotherapy on the oral bacterial flora: a pilot study. Oral Surg Oral Med Oral Pathol Oral Radiol Endod 2010;109(4):554-60.

37) Laheij AM, de Soet JJ, von dem Borne PA, Kuijper EJ, Kraneveld $\mathrm{EA}$, van Loveren $\mathrm{C}$, et al. Oral bacteria and yeasts in relationship to oral ulcerations in hematopoietic stem cell transplant recipients. Support Care Cancer 2012;20(12):3231-40.

38) Hu YJ, Shao ZY, Wang Q, Jiang YT, Ma R, Tang ZS, et al. Exploring the dynamic core microbiome of plaque microbiota during headand-neck radiotherapy using pyrosequencing. PLoS One 2013;8 (2):e56343.

39) Laheij AM, de Soet JJ. Can the oral microflora affect oral ulcerative mucositis? Curr Opin Support Palliat Care 2014;8(2):180-7.

40) Mitsuhashi K, Nosho K, Sukawa Y, Matsunaga Y, Ito M, Kurihara $\mathrm{H}$, et al. Association of Fusobacterium species in pancreatic cancer tissues with molecular features and prognosis. Oncotarget 2015;6 (9):7209-20.

41) West NR, Powrie F. Immunotherapy not working? Check your microbiota. Cancer Cell 2015;28(6):687-9. 


\section{정답 및 해설}

답 (3)

해설 외이도의 high-grade carcinoma의 경우 osseous EAC의 involving 또는 abutting 소견이 관찰되면 lateral temporal bone resection을 우선 고려하며, cartilaginous 또는 soft tissue invasion이 있는 경우 postoperative radiotherapy를 시행한다.

참고문헌: 1) 대한이비인후과학편. 이비인후과학-두경부외과학. 서울: 일조각;2009. p.562-3.

2) Fint, et al. Cummings Otolaryngology-Head and Neck Surgery. 6th ed. Elsevier;2015. p.2734-7.

답 (1)

해 설 외이도 다형선종의 조직학적 소견은 H-E stain에서 상피 및 근상피 세포의 관상구조가 보이고, 간질의 점액변성 및 연골 화생이 관찰된다.

참고문헌: 이비인후과학-두경부외과학. 대한이비인후과학편. 서울: 일조각;2009. p.563-6. 